University of Nebraska - Lincoln

DigitalCommons@University of Nebraska - Lincoln

Faculty Papers and Publications in Animal

Science

Animal Science Department

7-8-2003

\title{
Models with nuclear, cytoplasmic, and environmental effects for production traits of Columbia sheep
}

Kathryn J. Hanford

University of Nebraska, kathy.hanford@unl.edu

G. D. Snowder

USDA, ARS, U.S. Meat Animal Research Center

L. Dale Van Vleck

University of Nebraska-Lincoln, dvan-vleck1@unl.edu

Follow this and additional works at: https://digitalcommons.unl.edu/animalscifacpub

Part of the Animal Sciences Commons

Hanford, Kathryn J.; Snowder, G. D.; and Van Vleck, L. Dale, "Models with nuclear, cytoplasmic, and environmental effects for production traits of Columbia sheep" (2003). Faculty Papers and Publications in Animal Science. 200.

https://digitalcommons.unl.edu/animalscifacpub/200

This Article is brought to you for free and open access by the Animal Science Department at DigitalCommons@University of Nebraska - Lincoln. It has been accepted for inclusion in Faculty Papers and Publications in Animal Science by an authorized administrator of DigitalCommons@University of Nebraska - Lincoln. 


\title{
Models with nuclear, cytoplasmic, and environmental effects for production traits of Columbia sheep ${ }^{1}$
}

\author{
K. J. Hanford $\dagger$, G. D. Snowder $\$$, and L. D. Van Vleck $\dagger^{2}$ \\ USDA, ARS, U.S. Meat Animal Research Center, †Lincoln, NE 68583-0908 and $\ddagger$ Clay Center, NE 68933
}

\begin{abstract}
Statistical models (16) were compared for birth weight of 24,741 Columbia lambs recorded at the U.S. Sheep Experiment Station (USSES; 1950 to 1998). The goal was to estimate fractions of variance due to cytoplasmic line $\left(\mathrm{c}^{2} ; \mathrm{n}=590\right)$ and sire $\times$ cytoplasmic line interaction $\left(\mathrm{sc}^{2} ; \mathrm{n}=12,831\right)$ with other nuclear and environmental effects included in the model. The basic model included direct genetic (fractional variance, $\left.\mathrm{a}^{2} ; \mathrm{n}=26,623\right)$, maternal genetic $\left(\mathrm{m}^{2}\right.$, with direct-maternal correlation $\mathrm{r}_{\mathrm{am}}$ ), and maternal permanent environmental $\left(\mathrm{p}_{\mathrm{m}}^{2} ; \mathrm{n}=6,385\right)$ effects. The model with $\mathrm{sc}^{2}$ was significantly $(P<0.05)$ better than the basic model with $c^{2}$, but with other random effects added, $\mathrm{sc}^{2}$ became zero. Significant $(P<0.05)$ variance components were associated with random dam $\times$ year $\left(\mathrm{dy}^{2}\right)$ and dam $\times$ number born $\left(\mathrm{dn}^{2}\right)$ interaction effects. Estimates with all effects in the model were: $\mathrm{a}^{2}, 0.26$; $\mathrm{m}^{2}, 0.24 ; \mathrm{r}_{\mathrm{am}},-0.05 ; \mathrm{p}_{\mathrm{m}}^{2}, 0.02 ; \mathrm{c}^{2}, 0.00 ; \mathrm{dn}^{2}, 0.04 ; \mathrm{dy}^{2}$, $0.08 ; \mathrm{sd}^{2}, 0.04 ; \mathrm{sc}^{2}, 0.00$. Estimates for $\mathrm{a}^{2}, \mathrm{~m}^{2}$, and $\mathrm{r}_{\mathrm{am}}$ were the same for all models. Estimate of $\mathrm{p}_{\mathrm{m}}^{2}$ changed when other effects were added to the model. The largest
\end{abstract}

estimates for nongenetic effects were: $\mathrm{p}_{\mathrm{m}}^{2}, 0.06 ; \mathrm{c}^{2}, 0.00$; $\mathrm{dy}^{2}, 0.14 ; \mathrm{sd}^{2}, 0.13$; and $\mathrm{sc}^{2}, 0.04$. Parameter estimates were similar regardless of whether fixed genetic groups $(\mathrm{n}=84)$ were in the model. For weaning weight $(120 \mathrm{~d}$, $\mathrm{n}=23,903)$, estimates of variances of effects added to the basic model were all near zero $\left(\mathrm{a}^{2}, 0.14 ; \mathrm{m}^{2}, 0.09\right.$; $\left.\mathrm{r}_{\mathrm{am}}, 0.23 ; \mathrm{p}_{\mathrm{m}}^{2}, 0.04\right)$. For fleece weight $(\mathrm{FW}, \mathrm{n}=29,024)$ and number born (NB, $\mathrm{n}=29,688)$, animal permanent environmental effects were added to the model ( $\mathrm{p}_{\mathrm{a}}^{2} ; \mathrm{n}=$ 7,741 and 7,840 ) and $r_{a m}$ was dropped. For these traits, effects not in the basic model had small variances. For FW, estimates with the full model were: $\mathrm{a}^{2}, 0.52 ; \mathrm{m}^{2}$, $0.01 ; \mathrm{p}_{\mathrm{m}}^{2}, 0.00 ; \mathrm{p}_{\mathrm{a}}^{2}, 0.06 ; \mathrm{c}^{2}, 0.00 ; \mathrm{dy}^{2}, 0.00 ; \mathrm{sd}^{2}, 0.02 ;$ and $\mathrm{sc}^{2}, 0.06$, and for NB they were: $\mathrm{a}^{2}, 0.08 ; \mathrm{m}^{2}, 0.00 ; \mathrm{p}_{\mathrm{m}}^{2}$, $0.00 ; \mathrm{p}_{\mathrm{a}}^{2}, 0.02 ; \mathrm{c}^{2}, 0.00 ; \mathrm{dy}^{2}, 0.00 ; \mathrm{sd}^{2}, 0.00 ;$ and $\mathrm{sc}^{2}, 0.01$. Cytoplasmic effects were not important. Unusual random effects in the model did not change estimates for basic parameters. Although some effects were significant, especially for BW, effects on genetic evaluations are likely to be small.

Key Words: Cytoplasmic Inheritance, Genetic-Environment Interaction, Genetic Variation, Heritability

(2003 American Society of Animal Science. All rights reserved.

J. Anim. Sci. 2003. 81:1926-1932

\section{Introduction}

Recent studies on quantitative traits of cattle have not found cytoplasmic effects to be important, in contrast to earlier, less critical studies-for example, on dairy cattle (Bell et al., 1985; Boettcher and Gibson, 1997; Albuquerque et al., 1998) and on beef cattle (Tess et al., 1987; Tess and Robison, 1990; Tess and MacNeil, 1994). Kennedy (1986), in a classic study by simulation, showed that not accounting for genetic relationships would result in overestimation of variance due to cytoplasmic effects. Southwood et al. (1989), through simu-

\footnotetext{
${ }^{1}$ Published as paper No. 13939, Journal Ser., Nebraska Agric. Res. Div., Univ. of Nebraska, Lincoln 68583-0908.

${ }^{2}$ Correspondence: A218 Animal Sciences, University of Nebraska, Lincoln 68583-0908 (phone: 402-472-6010; fax: 402-472-6362; E-mail: lvanvleck@unlnotes.unl.edu).

Received December 6, 2002.

Accepted April 23, 2003.
}

lation, showed that under an additive maternal genetic model, a small cytoplasmic variance was estimated, although none was present. Specific mitochondrial types may influence milk production in dairy cattle (Faust et al., 1990; Schutz et al., 1994; Boettcher et al., 1996), carcass traits of Japanese Black cattle (Mannen et al., 1998), and litter size in pigs (Robison, 1998). Some interactions of mitochondrial and nuclear genomes have been identified in humans (Wolz et al., 1997) and cattle (Seelan and Grossman, 1992). Maniatis and Pollott (2002) recently found no evidence of cytoplasmic effects on weight traits of Suffolk lambs. Four traits (birth, weaning and fleece weights, and number of lambs born) of a Targhee sheep population, with records from 1950 to 1998 , were unaffected by cytoplasmic effects (Van Vleck et al., 2002).

Quantitative traits of sheep might not be expected to be influenced by cytoplasmic effects, but only one study of a meat-type breed (Maniatis and Pollett, 2002) and 
Table 1. Summary of number of records, means, and of levels by factor

for four traits of Columbia sheep ${ }^{\mathrm{a}}$

\begin{tabular}{lcccc}
\hline \hline Item & Birth weight, kg & Weaning weight, kg & Fleece weight, kg & No. born \\
\hline Records $^{\text {b }}$ & 24,741 & 23,903 & 29,024 & 29,688 \\
Mean & 4.89 & 35.7 & 5.31 & 1.29 \\
SD & 0.86 & 6.5 & 1.04 & 0.73 \\
Animals with records & 24,741 & 23,903 & 7,741 & 7,840 \\
Sires & 1,020 & 1,020 & 904 & 905 \\
Dams & 6,385 & 6,318 & 4,098 & 4,140 \\
Cytoplasmic line & 590 & 587 & 346 & 352 \\
Average animals/line & 41.9 & 40.7 & 22.4 & 22.3 \\
Dam $\times$ year & 18,336 & 18,089 & 7,017 & 7,099 \\
Sire $\times$ dam & 17,773 & 17,536 & 6,966 & 7,047 \\
Sire $\times$ cytoplasmic line & 12,831 & 12,698 & 5,828 & 5,892 \\
Dam $\times$ No. born & 9,836 & - & - & - \\
\hline
\end{tabular}

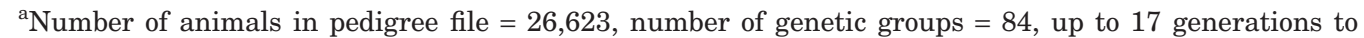
founder dam.

${ }^{\mathrm{b}}$ Means and standard deviations not adjusted for model effects.

one study of a dual-purpose synthetic breed (Van Vleck et al., 2002) have been fully reported. The purpose of this study was to compare estimates of variance due to nuclear, cytoplasmic, and environmental effects, and due to genotype $\times$ cytoplasmic effects for birth weight, weaning weight, fleece weight, and number of lambs born for Columbia sheep with those from a study of Targhee sheep (Van Vleck et al., 2002).

\section{Materials and Methods}

Data were records collected from 1950 to 1998 at the U.S. Sheep Experiment Station (USSES) in Dubois, Idaho, from the station's Columbia flock. As in the previous study with Targhee records (Van Vleck et al., 2002), Hanford (2001) had previously edited the data for estimation of genetic change over the 49-yr period. Ercanbrack and Knight (1991) have described the origin of the Columbia flock and its general management, as well as how weaning weight was adjusted to the standard 120-d age.

Means and levels of random factors describing the data for birth weight, weaning weight $(120 \mathrm{~d})$, fleece weight of ewes, and number of lambs born per ewe are in Table 1. Fixed factors for the analyses were the same

Table 2. Number of levels for fixed factors in models for analysis of four traits (birth weight, BWT; weaning weight, WWT; fleece weight, FLW; number born, NB)

\begin{tabular}{lcccc}
\hline \hline Factor & BWT & WWT & FLW & NB \\
\hline Year & 49 & 49 & 46 & 47 \\
Age dam (ewe) & 12 & 12 & $(12)$ & $(12)$ \\
Gender $^{\text {Type birth (TB) }}{ }^{\mathrm{a}}$ & 2 & 3 & - & - \\
TB and rearing $^{\mathrm{b}}$ & 4 & - & - & - \\
No. weaned & - & 8 & - & - \\
\hline
\end{tabular}

${ }^{\text {a }}$ Four types of birth; single, twin, triplet, quadruplet.

${ }^{b}$ Eight TB and rearing levels; single-single, single-twin, twin-single, twin-twin, triplet/quadruplet-single, triplet/quadruplet-twin, triplet/quadruplet-triplet, quadruplet-any type of rearing (used 1983 to 1992).
(Table 2) as those for the Targhee study (Van Vleck et al., 2002).

Cytoplasmic lines were defined by tracing all animals through the female line of descent to unique founding dams, which ranged from 346 to 590 , depending on the trait. The data were truncated in 1950 so pedigrees ending in 1950 might, if extended, be traced to fewer founding dams (Roughsedge et al., 2001). Rambouillet ewes were the source of all cytoplasmic effects in the creation of the Columbia breed, in contrast to the Targhee breed, which was not exclusively derived from Rambouillet ewes (Terrill, 1947). The interaction of genotype $\times$ cytoplasmic line effects or the interaction of nuclear and mitochrondrial genomes was modeled by including a random effect for sire $\times$ cytoplasmic line combination since sires were mated to ewes with various cytoplasmic origins.

Birth weight was the first trait analyzed. Initial models included direct and maternal genetic (with covariance), maternal permanent environmental, and residual environmental effects, as well as cytoplasmic line effects. The final part of the initial model was to include a dam $\times$ year interaction effect because sires were not repeated over years. The intent was to determine if including such a factor would affect estimates of genetic parameters including the direct-maternal genetic correlation.

In agreement with the previous Targhee study (Van Vleck et al., 2002) for birth weight, the estimate of the component of variance for dam $\times$ year effects was large (approximately $12 \%$ of phenotypic variance). The only way a dam could have more than one measure in a year was to have multiple births in at least one year. Therefore, dam $\times$ number born and sire $\times$ dam terms were added to the model. These effects are highly confounded and also confounded with levels of dam $\times$ year (Table 1). As with the previous Targhee report (Van Vleck et al., 2002), cytoplasmic line effects were found to be unimportant for birth weight, and more emphasis was put on the interaction of dam with year, number born, and sire in the model comparisons. 
Table 3. Possible random factors in models for analyses of four traits (birth weight, BWT; weaning weight, WWT; fleece weight, FLW; number born, NB)

\begin{tabular}{|c|c|c|c|c|}
\hline Factor & BWT & WWT & FLW & NB \\
\hline Animal genetic, $\mathrm{a}^{2}$ & $v$ & $\checkmark$ & $\checkmark$ & $\boldsymbol{v}$ \\
\hline Maternal genetic, $\mathrm{m}^{2}$ & $\checkmark$ & $\checkmark$ & $\checkmark$ & $\boldsymbol{v}$ \\
\hline Correlation, $\mathrm{r}_{\mathrm{am}}$ & $v$ & $\boldsymbol{v}$ & - & - \\
\hline Maternal permanent environmental, $\mathrm{p}_{\mathrm{m}}^{2}$ & $v$ & $\checkmark$ & $v$ & $\boldsymbol{v}$ \\
\hline Animal permanent environmental, $p_{a}^{2}$ & - & - & $\checkmark$ & $\boldsymbol{v}$ \\
\hline Cytoplasmic line, $c^{2}$ & $\checkmark$ & $\checkmark$ & $\checkmark$ & $\boldsymbol{\nu}$ \\
\hline Dam $\times$ year, $\mathrm{dy}^{2}$ & $\checkmark$ & $\checkmark$ & $\boldsymbol{v}$ & $\boldsymbol{v}$ \\
\hline Dam $\times$ number born, $\mathrm{dn}^{2}$ & $\checkmark$ & - & - & - \\
\hline Sire $\times$ dam, $\mathrm{sd}^{2}$ & $\checkmark$ & $\checkmark$ & $v$ & $\boldsymbol{v}$ \\
\hline Sire $\times$ cytoplasmic line, $\mathrm{sc}^{2}$ & $\checkmark$ & $\checkmark$ & $\checkmark$ & $\checkmark$ \\
\hline
\end{tabular}

Fewer models were used for the other traits because cytoplasmic line effects had essentially zero variances. For traits with repeated measures, (number born and fleece weight), animal and maternal permanent environmental effects were both included in some models.

Analyses with founder genetic groups $(\mathrm{n}=84)$ included as fixed effects were compared with analyses without founder groups (Westell et al., 1988). These groups were based on an animal's year of birth for sires and dams whose own records were not found in the database (Hanford, 2001). As with the Targhee study (Van Vleck et al., 2002), whether groups were in the model resulted in similar estimates for genetic parameters. Therefore, only the full and usual models were used with founder genetic groups in the model. Random factors included in models for the four traits are presented in Table 3.

Estimates of variance components were obtained by derivative-free REML (Smith and Graser, 1986) using the MTDFREML programs (Boldman et al., 1995). Standard errors for genetic parameters and for fractions of variance due to other factors were based on the delta method and average information matrix at convergence (e.g., Dodenhoff et al., 1998). Likelihood ratio tests (LRT) were used as a statistical comparison of models.

\section{Results}

\section{Birth Weight}

Estimates of components of variance and fractions of phenotypic variance from 16 models for birth weight are in Table 4 . The phenotypic variance ranged from 0.5381 to $0.5500 \mathrm{~kg}^{2}$. The general pattern of variance components estimates was similar to that for the Targhee breed (Van Vleck et al., 2002), which is another dual-purpose synthetic breed. The results will be summarized briefly. Models with and without fixed genetic group effects gave similar results (Models 1 vs. 3 and Models 2 vs. 15). Estimates of direct and maternal heritabilities and the direct-maternal genetic correlation were essentially the same for all models. Variance due to cytoplasmic lines was zero and was not significant in all models including cytoplasmic effects (Models 4, 10 to 12,15 , and 16). Adding dam $\times$ year interaction accounted for an additional $14 \%$ of the total variance (Model 5; $\mathbf{e}^{2}$, the fraction of variance due to residual effects, was reduced from 0.45 to 0.33 ) with only a slight reduction (from 0.06 to 0.04 ) in fraction of variance due to maternal permanent environmental effects $\left(p_{\mathbf{m}}^{2}\right)$. When the maternal permanent environment effect was dropped, the fraction of variance due to the dam $\times$ year interaction did not change (Model 6). Following the Targhee study (Van Vleck et al., 2002), dam $\times$ number born was then included as a random factor (Model 7). The fit of the model with dam $\times$ number born in the model (Model 7) was better than without the effect (Model 3), but added alone, it was not as good as with only dam $\times$ year effects added in the model (Models 5 and 6 ). The model was improved significantly by including both dam $\times$ year and dam $\times$ number born effects compared with models with only one of these factors (Model 8 vs. Models 5 and 7). The variance due to dam $\times$ number born was partitioned about equally from variance due to maternal permanent environmental effects and variance due to dam $\times$ year effects. The basic model was improved with sire $\times$ dam effects in the model (Model 9), as was expected due to obvious confounding with dam $\times$ year effects. The improvement in the log likelihood was not as great as with the addition of dam $\times$ year effects to the basic model (Model 5 ). The estimate of fractional variance due to sire $\times$ dam effects of 0.13 , which would correspond to a fractional estimate of dominance variance of about 0.50 , is much too large. When in the model with dam $\times$ year (Model 13) or with dam $\times$ year and dam $\times$ number born effects (Model 14), the estimate of fractional variance due to sire $\times$ dam effects was reduced to 0.04 , similar to the 0.05 reported for the Targhee study (Van Vleck et al., 2002). With sire $\times$ cytoplasmic line effects added to the basic model (Model 11), the LRT was significant, but the improvement was less than that found by adding other interaction effects. The relative estimate of 0.04 was reduced to zero when any of the other interaction effects with dam were in the model (Models 12, 15, and 16). The model with all three interactions with dam effects, in addition to the 
Table 4. Estimates of genetic parameters for birth weight with 16 models with standard errors (SE) for the complete model in bottom row ${ }^{\mathrm{ab}}$

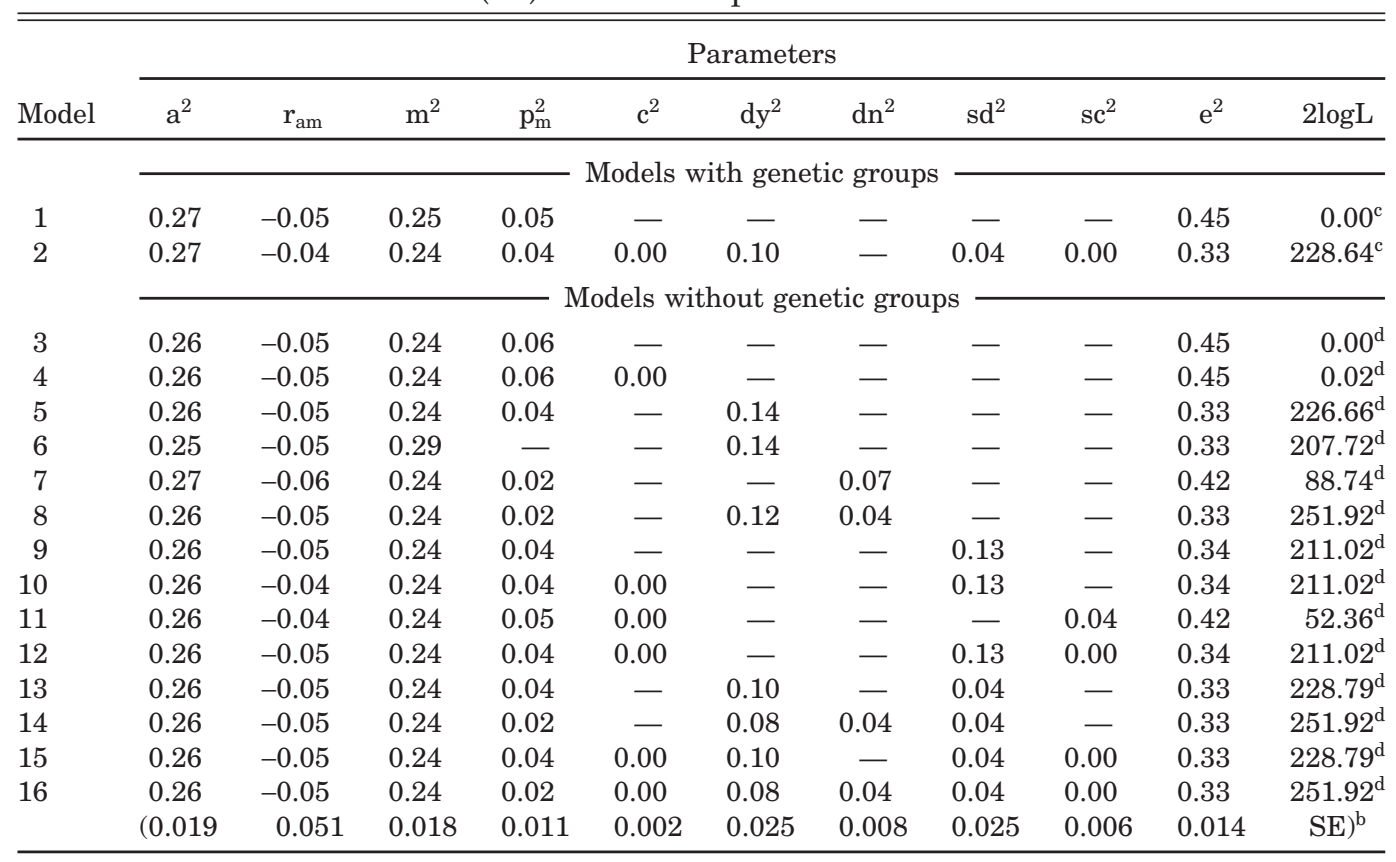

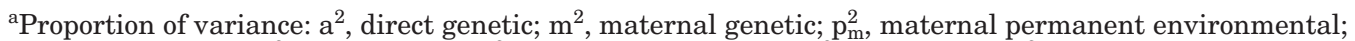
$\mathrm{c}^{2}$, cytoplasmic line; $\mathrm{dy}^{2}$, dam $\times$ year; $\mathrm{dn}^{2}$, dam $\times$ number born; $\mathrm{sd}^{2}$, sire $\times$ dam; $\mathrm{sc}^{2}$, sire $\times$ cytoplasmic line; $\mathrm{e}^{2}$, temporary environmental; $\mathrm{r}_{\mathrm{am}}$, direct-maternal genetic correlation; phenotypic variance: 0.5381 to 0.5500 $\mathrm{kg}^{2}$.

${ }^{\mathrm{b}} \mathrm{SE}$ for model not including genetic groups.

${ }^{\mathrm{c}}$ Difference in $2 \log$ likelihood (2logL) from usual model $\left(\mathrm{a}^{2}, \mathrm{r}_{\mathrm{am}}, \mathrm{m}^{2}, \mathrm{p}_{\mathrm{m}}^{2}\right)$ with genetic groups in model.

${ }^{\mathrm{d} D i f f e r e n c e}$ in $2 \log$ likelihood from usual model $\left(\mathrm{a}^{2}, \mathrm{r}_{\mathrm{am}}, \mathrm{m}^{2}, \mathrm{p}_{\mathrm{m}}^{2}\right)$ with genetic groups not in model.
}

basic direct-maternal model, was not significantly different from the model including only dam $\times$ year and dam $\times$ number born effects (Model 14 vs. 8 ). The sire $\times$ dam fraction seems to come entirely from the dam $\times$ year component of variance. Cytoplasmic line and sire $\times$ cytoplasmic line effects contribute little to nothing to variation in birth weight.

Al-Shorepy and Notter (1998) reported that litter effects (comparable to the dam $\times$ year effect) account for about $17 \%$ of variation in birth weight. Notter (personal communication) indicated that unpublished analyses of birth weights of Targhee, Suffolk, and Polypay lambs included in the National Sheep Improvement Program have shown large and significant variance components for litter effects. A reviewer of the Targhee study (Van Vleck et al., 2002) suggested that much of the variance due to dam $\times$ year and dam $\times$ number born effects may be due to year-specific effects on lambs in the same litter in that, if the effects result in light (or heavy) birth weight for one member of the litter, weights of others in the litter will be similar.

\section{Weaning Weight}

Estimates of fractional variances for weaning weight are in Table 5. The phenotypic variances ranged from 27.27 to $27.73 \mathrm{~kg}^{2}$. The pattern of estimates for weaning weight did not follow the same pattern as estimates for birth weight. As with the Targhee study (Van Vleck et al., 2002), none of the four effects added to the basic model improved the likelihood. Estimates of fractional contributions of each of the four "extra" factors were zero.

Estimates of fractional variances from models with and without genetic groups (Model 1 vs. 3 and Model 2 vs. 11) were only slightly different, indicating the main difference was in the estimate of the direct-maternal genetic correlation.

Lack of evidence for cytoplasmic or genotype $\times$ cytoplasmic effects is in agreement with the similar study of Targhee weaning weights (Van Vleck et al., 2002). Also, Maniatis and Pollott (2002) found no evidence for cytoplasmic effects for 8-wk and 146-d weights.

\section{Fleece Weight}

Estimates of fractional variances for fleece weight are in Table 6 . The phenotypic variances ranged from 0.8374 to $0.8617 \mathrm{~kg}^{2}$. Although variances due to maternal genetic and permanent environmental effects were small, these analyses resulted in a significant LRT for the model including both maternal effects compared to a model without maternal effects (Model 3 vs. 5). Even though the estimate of maternal heritability was low (about 0.01), for consistency with the other traits, the factor was included in most models. The variance due to maternal permanent effects was near zero, so that factor was dropped from further analyses. The direct- 
Table 5. Estimates of genetic parameters for weaning weight with 11 models with standard errors for the complete model in bottom row ${ }^{\text {ab }}$

\begin{tabular}{|c|c|c|c|c|c|c|c|c|c|c|}
\hline \multirow[b]{2}{*}{ Model } & \multicolumn{10}{|c|}{ Parameters } \\
\hline & $a^{2}$ & $\mathrm{r}_{\mathrm{am}}$ & $\mathrm{m}^{2}$ & $\mathrm{p}_{\mathrm{m}}^{2}$ & $c^{2}$ & $d y^{2}$ & $\mathrm{sd}^{2}$ & $\mathrm{sc}^{2}$ & $\mathrm{e}^{2}$ & $2 \log \mathrm{L}$ \\
\hline & & & & $-\mathrm{M}$ & els witl & enetic & ups & & & \\
\hline 1 & 0.16 & 0.35 & 0.09 & 0.03 & - & - & - & - & 0.68 & $0.00^{\mathrm{c}}$ \\
\hline \multirow[t]{2}{*}{2} & 0.16 & 0.35 & 0.09 & 0.03 & 0.00 & 0.00 & 0.00 & 0.00 & 0.68 & $0.00^{\mathrm{c}}$ \\
\hline & \multicolumn{10}{|c|}{ Models without genetic groups } \\
\hline 3 & 0.14 & 0.23 & 0.09 & 0.04 & - & - & - & - & 0.71 & $0.00^{\mathrm{d}}$ \\
\hline 4 & 0.14 & 0.23 & 0.09 & 0.04 & 0.00 & - & - & - & 0.71 & $0.00^{\mathrm{d}}$ \\
\hline 5 & 0.14 & 0.23 & 0.09 & 0.04 & - & 0.00 & - & - & 0.71 & $0.00^{\mathrm{d}}$ \\
\hline 6 & 0.13 & 0.24 & 0.13 & - & - & 0.00 & - & - & 0.71 & $-21.38^{\mathrm{d}}$ \\
\hline 7 & 0.14 & 0.23 & 0.09 & 0.04 & - & - & 0.00 & - & 0.71 & $0.00^{\mathrm{d}}$ \\
\hline 8 & 0.14 & 0.23 & 0.09 & 0.04 & 0.00 & - & - & 0.00 & 0.70 & $0.00^{\mathrm{d}}$ \\
\hline 9 & 0.14 & 0.23 & 0.09 & 0.04 & 0.00 & - & 0.00 & - & 0.71 & $0.00^{\mathrm{d}}$ \\
\hline 10 & 0.14 & 0.23 & 0.09 & 0.04 & 0.00 & - & 0.00 & 0.00 & 0.71 & $0.00^{\mathrm{d}}$ \\
\hline \multirow[t]{2}{*}{11} & 0.14 & 0.23 & 0.09 & 0.04 & 0.00 & 0.00 & 0.00 & 0.00 & 0.71 & $0.00^{\mathrm{d}}$ \\
\hline & $(0.014$ & 0.094 & 0.012 & 0.009 & 0.002 & 0.033 & 0.032 & 0.017 & 0.016 & $\mathrm{SE})^{\mathrm{b}}$ \\
\hline
\end{tabular}

aproportion of variance: $\mathrm{a}^{2}$, direct genetic; $\mathrm{m}^{2}$, maternal genetic; $\mathrm{p}_{\mathrm{m}}^{2}$, maternal permanent environmental; $\mathrm{c}^{2}$, cytoplasmic line; $\mathrm{dy}^{2}$, dam $\times$ year; $\mathrm{dn}^{2}$, dam $\times$ number born; $\mathrm{sd}^{2}$, sire $\times$ dam; $\mathrm{sc}^{2}$, sire $\times$ cytoplasmic line; $\mathrm{e}^{2}$, temporary environmental; $r_{\mathrm{am}}$, direct-maternal genetic correlation; phenotypic variance: 27.27 to 27.73 $\mathrm{kg}^{2}$.

${ }^{\mathrm{b}} \mathrm{SE}$ for model not including genetic groups.

${ }^{\mathrm{c}}$ Difference in 2log likelihood (2logL) from usual model $\left(\mathrm{a}^{2}, \mathrm{r}_{\mathrm{am}}, \mathrm{m}^{2}, \mathrm{p}_{\mathrm{m}}^{2}\right)$ with genetic groups in model.

${ }^{\mathrm{d} D i f f e r e n c e}$ in $2 \log$ likelihood from usual model $\left(\mathrm{a}^{2}, \mathrm{r}_{\mathrm{am}}, \mathrm{m}^{2}, \mathrm{p}_{\mathrm{m}}^{2}\right)$ with genetic groups not in model.

maternal genetic covariance was not included in the model because of the low maternal heritability. Estimates of direct and maternal heritabilities were the same no matter what other effects were included in the model. Similarly, estimates of fractional variances were the same regardless of whether genetic groups were in the models (Model 1 vs. 3 and 2 vs. 10). Variance due to cytoplasmic lines was near zero (Model 10). The estimate of fraction of variance due to sire $\times$ dam effects was 0.02 , which was not significantly different from zero. Adding a dam $\times$ year interaction accounted for $11 \%$ of the total variance (Model 6). All of the variance due to this effect seems to be partitioned from variance due to individual permanent environmental effects.

Table 6. Estimates of genetic parameters for fleece weight with 10 models with standard errors for the complete model in bottom row ${ }^{\text {ab }}$

\begin{tabular}{|c|c|c|c|c|c|c|c|c|c|c|}
\hline \multirow[b]{2}{*}{ Model } & \multicolumn{10}{|c|}{ Parameters } \\
\hline & $a^{2}$ & $\mathrm{~m}^{2}$ & $\mathrm{p}_{\mathrm{m}}^{2}$ & $\mathrm{p}_{\mathrm{a}}^{2}$ & $c^{2}$ & $d y^{2}$ & $\mathrm{sd}^{2}$ & $\mathrm{sc}^{2}$ & $\mathrm{e}^{2}$ & $2 \log L$ \\
\hline & & & & $-\mathrm{M}$ & els with & enetic g & ups & & & \\
\hline 1 & 0.51 & 0.02 & 0.00 & 0.13 & - & - & - & - & 0.33 & $0.00^{\mathrm{c}}$ \\
\hline \multirow[t]{2}{*}{2} & 0.52 & 0.01 & 0.00 & 0.06 & 0.00 & 0.01 & 0.00 & 0.06 & 0.33 & $32.78^{\mathrm{c}}$ \\
\hline & \multicolumn{10}{|c|}{ Models without genetic groups } \\
\hline 3 & 0.53 & 0.01 & 0.02 & 0.12 & - & - & - & - & 0.33 & $0.00^{\mathrm{d}}$ \\
\hline 4 & 0.53 & - & 0.02 & 0.12 & - & - & - & - & 0.33 & $-1.32^{\mathrm{d}}$ \\
\hline 5 & 0.53 & - & - & 0.14 & - & - & - & - & 0.33 & $-11.40^{\mathrm{d}}$ \\
\hline 6 & 0.55 & 0.01 & - & 0.00 & - & 0.11 & - & - & 0.32 & $-1.29^{\mathrm{d}}$ \\
\hline 7 & 0.55 & 0.01 & - & - & - & 0.11 & - & - & 0.32 & $-1.31^{\mathrm{d}}$ \\
\hline 8 & 0.52 & 0.01 & - & 0.08 & 0.00 & - & - & 0.06 & 0.33 & $33.73^{\mathrm{d}}$ \\
\hline 9 & 0.52 & 0.01 & - & 0.06 & 0.00 & 0.02 & - & 0.06 & 0.33 & $34.37^{\mathrm{d}}$ \\
\hline \multirow[t]{2}{*}{10} & 0.52 & 0.01 & 0.00 & 0.06 & 0.00 & 0.00 & 0.02 & 0.06 & 0.33 & $34.43^{\mathrm{d}}$ \\
\hline & $(0.019$ & 0.009 & 0.009 & 0.022 & 0.004 & 0.041 & 0.041 & 0.013 & 0.006 & $\mathrm{SE})^{\mathrm{b}}$ \\
\hline
\end{tabular}

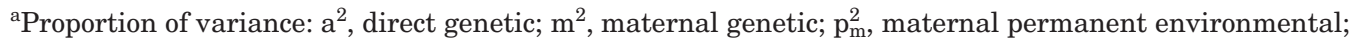
$\mathrm{p}_{\mathrm{a}}^{2}$, animal permanent environmental; $\mathrm{c}^{2}$, cytoplasmic line; $\mathrm{dy}^{2}$, dam $\times$ year; $\mathrm{dn}^{2}$, dam $\times$ number born; $\mathrm{sd}^{2}$, sire $\times$ dam; $\mathrm{sc}^{2}$, sire $\times$ cytoplasmic line; $\mathrm{e}^{2}$, temporary environmental; $\mathrm{r}_{\mathrm{am}}$, direct-maternal genetic correlation; phenotypic variance: 0.8374 to $0.8617 \mathrm{~kg}^{2}$.

${ }^{\mathrm{b}} \mathrm{SE}$ for model not including genetic groups.

${ }^{\mathrm{c}}$ Difference in $2 \log$ likelihood (2logL) from usual model $\left(\mathrm{a}^{2}, \mathrm{~m}^{2}, \mathrm{p}_{\mathrm{m}}^{2}, \mathrm{p}_{\mathrm{a}}^{2}\right)$ with genetic groups in model.

${ }^{\mathrm{d}}$ Difference in $2 \log$ likelihood from usual model $\left(\mathrm{a}^{2}, \mathrm{~m}^{2}, \mathrm{p}_{\mathrm{m}}^{2}, \mathrm{p}_{\mathrm{a}}^{2}\right)$ with genetic groups not in model. 
Table 7. Estimates of genetic parameters for number born with five models with standard errors for the complete model in bottom row ${ }^{\mathrm{ab}}$

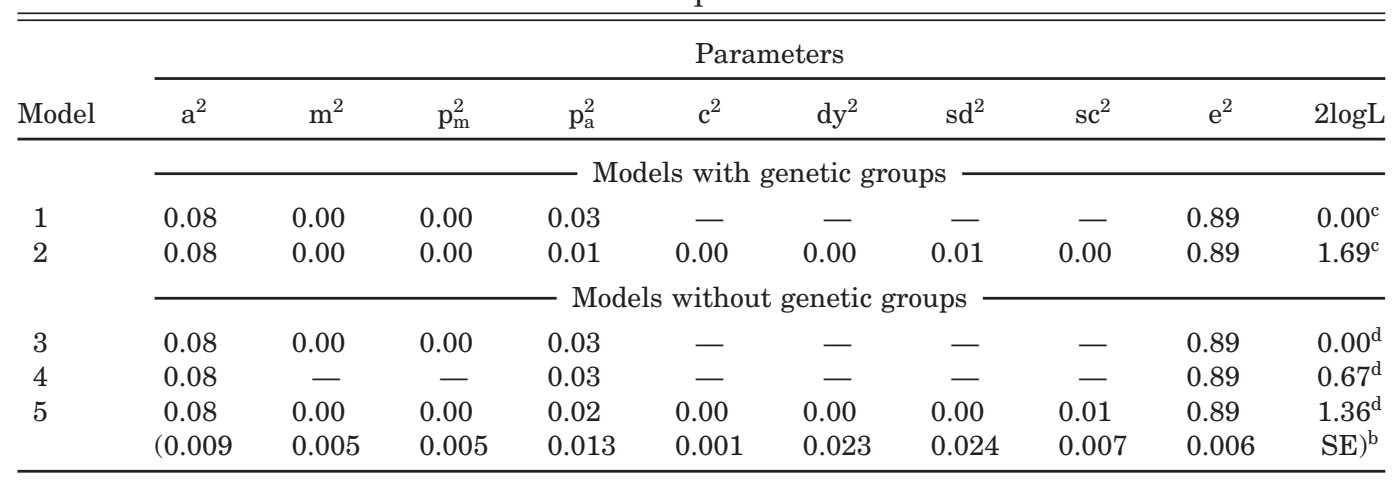

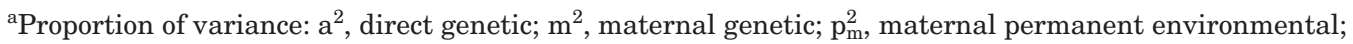
$\mathrm{p}_{\mathrm{a}}^{2}$, animal permanent environmental; $\mathrm{c}^{2}$, cytoplasmic line; $\mathrm{dy}^{2}$, dam $\times$ year; $\mathrm{sd}^{2}$, sire $\times$ dam; $\mathrm{sc}^{2}$, sire $\times$ cytoplasmic line; $\mathrm{e}^{2}$, temporary environmental; phenotypic variance: 0.4147 to 0.4152 .

${ }^{\mathrm{b}} \mathrm{SE}$ for model not including genetic groups.

${ }^{\mathrm{c} D i f f e r e n c e}$ in $2 \log$ likelihood (2logL) from usual model $\left(\mathrm{a}^{2}, \mathrm{~m}^{2}, \mathrm{p}_{\mathrm{m}}^{2}, \mathrm{p}_{\mathrm{a}}^{2}\right)$ with genetic groups in model.

${ }^{\mathrm{d} D i f f e r e n c e ~ i n ~} 2 \log$ likelihood from usual model $\left(\mathrm{a}^{2}, \mathrm{~m}^{2}, \mathrm{p}_{\mathrm{m}}^{2}, \mathrm{p}_{\mathrm{a}}^{2}\right)$ with genetic groups not in model.
}

Adding sire $\times$ cytoplasmic line effects to the model increased the likelihood (Model 8). Much of the variance due to this effect also seems to be partitioned from variance due to individual permanent environmental effects. Addition of the dam $\times$ year effect to the sire $\times$ cytoplasmic line effect did not significantly improve the model (Model 9). When both maternal effects are dropped from the model, the variances of those effects seemed also to go to the direct permanent environmental variance (Model 5). The small maternal genetic variance for fleece weight might be attributed to the influence of postnatal nutrition of lambs on the capacity of wool follicles to produce fiber (Corbett, 1979).

\section{Number Born}

Estimates of fractional variances for number of lambs born are in Table 7 . The phenotypic variances ranged from 0.4147 to 0.4152 . As with the other traits and estimates from the Targhee analyses (Van Vleck et al., 2002), estimates of variance due to cytoplasmic effects were near zero. Estimates of fractional variance were the same whether or not genetic groups were included in the model (Model 1 vs. 3 and 2 vs. 5). Direct heritability was the same with all models. No other sources of variation were significant. Including sire $\times$ cytoplasmic line effects partitioned variance from the relatively small component of variance due to animal permanent environmental effects (Model 5). The estimate of fractional variance was about the same size as the standard error. A model with direct genetic value and animal permanent environmental effects would seem to be adequate for genetic evaluation (Model 4). The estimates of variance components and estimates of variances are nearly the same as those reported by Rao and Notter (2000) and in the parallel study of Targhee sheep (Van Vleck et al., 2002).

\section{Discussion}

Cytoplasmic line effects were not important for any of the four traits analyzed. The variance component due to the interaction of nuclear and cytoplasmic genomes modeled as sire $\times$ cytoplasmic line effects was near zero for all traits except fleece weight, which could be due to confounding with other interaction effects. For genetic evaluations of weaning weight, the standard maternal effects model would be optimal. For fleece weight, a model with direct animal and maternal genetic effects and with an animal permanent environmental effect would be adequate. For number born, a model with direct animal genetic and permanent environmental effects would be sufficient.

The results for birth weight are puzzling but agree with other studies with litter effects in the model (AlShorepy and Notter, 1998) and with a similar study of birth weight of Targhee lambs (Van Vleck et al., 2002). Of the nontraditional factors added to the model, only cytoplasmic effects did not improve the model. The four interaction effects are highly confounded, but only the variance of sire $\times$ cytoplasmic line effects becomes zero when all four effects are in the model. The other three jointly reduce residual variance by about one-quarter, from 0.45 to 0.33 of phenotypic variance. The maternal (dam) permanent environmental variance was decreased from 0.06 to 0.04 or 0.02 of phenotypic variance when the interaction of dam with year or dam with number born was included in the model. Including sire $\times$ dam effects in the model slightly reduced the proportion of total variance from maternal permanent environmental effects from 0.06 to 0.04 . Including dam $\times$ year effects reduced the sire $\times$ dam component of variance from 0.13 to 0.04 of phenotypic variance in much the same pattern as for Targhee birth weights (Van Vleck et al., 2002). The non-zero estimate for the sire 
$\times$ dam component of variance with other effects in the model is not significant but also was non-zero and significant in the Targhee analysis (Van Vleck et al., 2002). For birth weight, estimates of the basic genetic parameters were not affected by adding nontraditional factors to the model. Although further study is needed, this result, in agreement with the Targhee study (Van Vleck et al., 2002), suggests that the standard model with addition of dam $\times$ year (or litter) effects (Al-Shorepy and Notter, 1998) would be relatively robust for ranking on EBV. Further investigation to explain why modeling the covariance between littermates (which exists only with more than one lamb in a litter) improves the likelihood is warranted.

\section{Implications}

For Columbia sheep, cytoplasmic effects seem unimportant for birth and weaning weight, fleece weight, and number of lambs born. Models for genetic evaluation of ewes for weaning weight and fleece weight and number of lambs born would not need to include interactions between dams and years or dams and sires. Standard models including direct and maternal genetic effects and, as appropriate, either direct or maternal permanent environmental effects are adequate. Further study may be needed to understand why interactions of dam with year and with number born, and possibly, with sire are important.

\section{Literature Cited}

Albuquerque, L. G., J. F. Keown, and L. D. Van Vleck. 1998. Variances of direct genetic effects, maternal genetic effects, and cytoplasmic inheritance effects for milk yield, fat yield, and fat percentage. J. Dairy Sci. 81:544-549.

Al-Shorepy, S. A., and D. R. Notter. 1998. Genetic parameters for lamb birth weight in spring and autumn lambing. Anim. Sci. 67:327-332.

Bell, B. R., B. T. McDaniel, and O. W. Robison. 1985. Effects of cytoplasmic inheritance on production traits of dairy cattle. J. Dairy Sci. 68:2038-2051.

Boettcher, P. J., A. E. Freeman, S. D. Johnson, R. K. Smith, D. C. Beitz, and B. T. McDaniel. 1996. Relationships between polymorphism for mitochondrial deoxyribonucleic acid and yield traits of Holstein cattle. J. Dairy Sci. 79:647-654.

Boettcher, P. J., and J. P. Gibson. 1997. Estimation of variance of maternal lineage effects among Canadian Holsteins. J. Dairy Sci. 80:2167-2176.

Boldman, K. G., L. A. Kriese, L. D. Van Vleck, C. P. Van Tassell, and S. D. Kachman. 1995. A Manual for Use of MTDFREML. USDA, ARS, Clay Center, NE.

Corbett, J. L. 1979. Variation in wool growth with physiological state. Pages 79-98 in Physiological and Environmental Limitations to Wool Growth. J. L. Black and P. J. Reis, ed. Univ. New England Pub. Unit. Armidale, Australia.

Dodenhoff, J., L. D. Van Vleck, S. D. Kachman, and R. M. Koch. 1998. Parameter estimates for direct, maternal and grandmaternal genetic effects for birth weight and weaning weight in Hereford cattle. J. Anim. Sci. 76:2521-2527.

Ercanbrack, S. K., and A. D. Knight. 1991. Effects of inbreeding on reproduction and wool production of Rambouillet, Targhee, and Columbia ewes. J. Anim. Sci. 69:4734-4744.

Faust, M. A., O. W. Robison, and B. T. McDaniel. 1990. Animal model estimates of cytoplasmic line constants for yield in Holsteins. J. Anim. Breed. Genet. 107:401-410.

Hanford, K. J. 2001. Estimates of genetic parameters and genetic change for prolificacy, weight, and wool characteristics of Columbia, Targhee and Polypay sheep. Ph.D. Diss. Univ. of Nebraska, Lincoln.

Kennedy, B. W. 1986. A further look at evidence for cytoplasmic inheritance of production traits in dairy cattle. J. Dairy Sci. 69:3100-3105.

Maniatis, N., and G. E. Pollott. 2002. Nuclear, cytoplasmic, and environmental effects on growth, fat, and muscle traits in Suffolk lambs from a sire referencing scheme. J. Anim. Sci. 80:57-67.

Mannen, H., T. Kojima, K. Oyama, F. Mukai, T. Ishida, and S. Tsuji. 1998. Effect of mitochondrial DNA variation on carcass traits of Japanese Black Cattle. J. Anim. Sci. 76:36-41.

Rao, S., and D. R. Notter. 2000. Genetic analysis of litter size in Targhee, Suffolk, and Polypay sheep. J. Anim. Sci. 78:21132120 .

Robison, O. W. 1998. Evidence for cytoplasmic influence on litter size in swine. In Proc. 6th World Cong. Genet. Appl. Livestock Prod., Armidale, Australia. 27:35-38.

Roughsedge, T., S. Brotherstone, and P. M. Visscher. 2001. Bias and power in the estimation of a maternal family variance component in the presence of incomplete and incorrect pedigree information. J. Dairy Sci. 84:944-950.

Schutz, M. M., A. E. Freeman, G. L. Lindberg, C. M. Koehler, and D. C. Beitz. 1994. The effect of mitochondrial DNA on milk production and health of dairy cattle. Livest. Prod. Sci. 37:283-295.

Seelan, R. S., and L. I. Grossman. 1992. Structure and organization of the heart isoform gene for bovine cytochrome c oxidase subunit VIIa. Biochemistry 31:4969-4704.

Smith, S. P., and H.-U. Graser. 1986. Estimating variance components in a class of mixed models by restricted maximum likelihood. J. Dairy Sci. 69:1156-1165.

Southwood, O. I., B. W. Kennedy, K. Meyer, and J. P. Gibson. 1989. Estimation of additive maternal and cytoplasmic genetic variances in animal models. J. Dairy Sci. 72:3006-3012.

Terrill, C. E. 1947. Breed crosses used in the development of Targhee sheep. J. Anim. Sci. 6:83-92.

Tess, M. W., and M. D. MacNeil. 1994. Evaluation of cytoplasmic genetic effects in Miles City Line 1 Hereford cattle. J. Anim. Sci. 72:851-856.

Tess, M. W., C. Reodecha, and O. W. Robison. 1987. Cytoplasmic genetic effects on preweaning growth and milk yield in Hereford cattle. J. Anim. Sci. 65:675-684.

Tess, M. W., and O. W. Robison. 1990. Evaluation of cytoplasmic genetic effects in beef cattle using an animal model. J. Anim. Sci. 68:1899-1909.

Van Vleck, L. D., G. D. Snowder, and K. J. Hanford. 2002. Models with cytoplasmic effects for birth, weaning and fleece weights, and litter size at birth for a population of Targhee sheep. J. Anim. Sci. 81:630-640.

Westell, R. A., R. L. Quaas, and L. D. Van Vleck. 1988. Genetic groups in an animal model. J. Dairy Sci. 71:1310-1318.

Wolz, W., W. Kress, and C. R. Mueller. 1997. Genomic sequence and organization of the human gene for cytochrome c oxidase subunit (COX7A1) VIIa-M. Genomics 45:438-442. 